Maja Žebčević Matić

DOI: https://dx.doi.org/10.21857/m16wjce7o9

Stručni članak

Rukopis prihvaćen za tisak: 21.12.2020.

\title{
MUZEJ U LONCU, MUZEJSKA BRIJAČNICA I GRGUREVO - POŽEŠKI EKOMUZEJ, ZAŠTO DA I ZAŠTO NE
}

\begin{abstract}
Sažetak
Požega kao grad koji obiluje kulturnom baštinom i kreativnim ljudima zaslužuje da se barem razmotri ideja ekomuzeja kao načina suvremene muzeološke interpretacije koja počiva na zajedništvu s cijelom zajednicom.

Činjenica je da su projekti koji prelaze okvire uobičajenog muzejskog djelovanja i razmišljanja u našim sredinama kratka daha.

Razlog tome, sudeći po Мuzeju u loncu (neuobičajenoj interpretaciji nematerijalne kulturne baštine putem okusa i mirisa zaboravljenih jela), ali i Muzejskoj brijačnici, čija se ideja zasniva na oživljavanju postojećeg muzejskog predmeta in situ (namještaja i opreme brijačnice s početka 20. stoljeća), jest problem muzeja da se uza svoju ustaljenu djelatnost i postojeće probleme teško nosi s organizacijskim i zakonskim ograničenjima i zahtjevima takvih muzejskih projekata.

Po tome se čini logičnim postaviti sudbinu tih dvaju projekata u okvir djelovanja jedinstvenog ekomuzeja koji će pokrenuti zajednicu oko samoodrživog modela prezentacije duha i nekadašnjega načina života grada.

Ako njima dodamo još i običaj Grgureva, koji se u novim uvjetima drastično i bez kontrole mijenja gubeći uporište u zajednici koja ga sve manje doživljava kao dio svojeg identiteta, o Ekomuzeju Požega vrijedilo bi ozbiljno razmisliti.
\end{abstract}

Ključne riječi: Ekomuzej; Muzej u loncu; Grgurevo; Muzejska brijačnica.

\section{Požeški baštinski potencijali}

U želji da se otvori zajednici, ali i širem krugu posjetitelja, da poveća vidljivost te da skrene pozornost na svoju misiju stručnog i aktivnog čuvara i interpretatora materijalne i nematerijalne kulturne baštine, Gradski muzej Požega u razdoblju između 2012. i 2018. godine konceptualno je osmislio dva vrijedna projekta tipa otvorenog muzeja, Muzej u loncu i Muzejska brijačnica. 


\section{Миzеј и loncu}

Ideja projekta Muzej u loncu jest da se istraživanjem i dokumentiranjem pripreme gotovo zaboravljenih jela koja pripadaju tradicijskoj prehrani Požege i Požeštine te cijele istočne Hrvatske na muzeološki inovativan način interpretiraju godišnji, životni i radni običaji te povijesni konteksti u kojima su jela nastajala, sociološka pozadina i njihova genealogija u okviru novog stalnog postava. ${ }^{1}$ Nadalje, zadaci su projekta omogućiti vidljivost i prepoznatljivost, a samim time zaštitu od nestanka mnogih jela, a s njima i dijelova baštine i identiteta. Cilj je senzibilizirati javnost i muzeje na lokalnoj, ali i regionalnoj razini za vrijednost tradicijskih jela u interpretaciji običaja i povijesti te osvijestiti ekološke, turističke i ugostiteljske potencijale svakog jela u smjeru jačanja poljoprivredno-gospodarskih kapaciteta istočne Hrvatske te, konačno, povećati vidljivost Gradskog muzeja Požega.

Autorica, muzejska etnologinja Maja Žebčević Matić, uz pomoć kolege Borisa Kneza, fotografa i tehničkog realizatora projekta, osmislila je brojne načine i metode za postizanje navedenih ciljeva. Prije svega ostvarena je suradnja sa zajednicom pri istraživanju i dokumentiranju pripreme izabranih jela. Pokrenut je blog Muzej u loncu kao virtualni muzej nematerijalne kulturne baštine s receptima i baštinskim pričama, tiskana je istoimena monografija, postavljene su dvije izložbe, odrađene su brojne radionice, snimljena su dva dokumentarna filma te su ostvareni suradnja i partnerstvo u raznim projektima s turističkim zajednicama, lokalnim ugostiteljima i školama. Osmišljena je forma otvorenog muzeja u smislu demonstriranja i natjecanja u pripremanju zaboravljenih jela s interpretacijom baštine na otvorenim javnim površinama tipa cooking showa.

Iako je dobio tri stručne i turističke nacionalne nagrade te nominaciju za međunarodnu stručnu nagradu ${ }^{2}$, čini se da projekt Muzej u loncu nije prepoznat u vlastitoj sredini.

Prije svega problem je u stavu dijela struke, pa čak i unutar samog Gradskog muzeja Požega, da je Muzej u loncu muzeološki nepotvrđena koncepcija interpretacije baštine koja dovodi do loše percepcije muzeja u javnosti ponajviše zbog neprimjerenosti organiziranja ili same pripreme hrane u muzeju i oko muzeja. Drugi problem leži u još uvijek nedovoljnom zajedništvu, nepovezanosti lokalne zajednice, koja uza sve napore muzeja nije prepoznala predložene mogućnosti iskorištavanja tog baštin-

1 Muzeološka koncepcija novog postava iz 2005. autorica Dubravke Sokač Štimac, Mirjane Šperande, Lidije Španiček, Dubravke Matoković i Maje Žebčević Matić predvidjela je i prostor za tu i takvu vrstu interpretacije nematerijalne kulturne baštine u okviru budućeg stalnog postava (str. 24).

2 Nagrada Simply the best, Way of Croatia sa zlatnim znakom, 2014.; Priznanje Čovjek ključ uspjeha Maji Žebčević Matić u kategoriji djelatnika u objektu kulturnog nasljeđa, 2015.; Posebno priznaje Hrvatskog muzejskog društva za projekt Muzej u loncu, 2016.; nominacija za Nagradu Živa Slavenskog foruma kulture za projekt Muzej u loncu, 2017. 
skog resursa za vlastitu dobrobit. Ako se koje predloženo tradicijsko jelo i nalazi na meniju restorana, do gosta dolazi uglavnom bez njegove interpretacijske vrijednosti koju projekt predlaže.

\section{Muzejska brijačnica}

Ideja o muzeološkom potencijalu otvorenog muzeja, odnosno interpretacije in situ interijera brijačnice s početka 20. stoljeća na Trgu Svetog Trojstva 15, rodila se u trenutku kada je 2015. godine odlaskom u mirovinu posljednjeg požeškog brijača zainteresirana javnost novinskim napisima potaknula požeški muzej i Grad Požegu da pronađu financijske okvire i otkupom spase inventar brijačnice. ${ }^{3}$ Još je 2013. godine utvrđeno kako su čitav inventar brijačnice i oprema iznenađujuće dobro sačuvani te čine u Hrvatskoj jedinstvenu cjelinu brijačkog obrta s početka 20. stoljeća, čime je od Uprave za zaštitu kulturne baštine Ministarstva kulture Republike Hrvatske dobila status kulturnog dobra. ${ }^{4}$

Inventar brijačnice otkupom je postao muzejski predmet in situ. ${ }^{5} \mathrm{~S}$ obzirom na to da u gradu Požegi danas više nema nijednog muškog brijača ni brijačnice, zadatak je bio osmisliti program koji će osim interijera, sada muzejskog predmeta, zaštititi i izumrlu vještinu muškog brijanja i šišanja, osvijestiti sociološku važnost tradicijskih brijačnica kao važnih mjesta okupljanja u prošlosti grada te pomoći da se atraktivna i dobra lokacija na glavnom trgu ne pretvori u lošu muzejsku čuvaonicu. ${ }^{6}$

Dakle, $\mathrm{u}$ želji da se prostor stare brijačnice ponovno oživi, muzej je osmislio koncept otvorenog muzeja - Muzejske brijačnice simboličnog naziva Ajmo (se) brijat. U traženju modela kako da se trajno osigura život toj ideji, muzej je njezinu opravdanost $\mathrm{u}$ javnosti nastojao ispitati kroz svoje programe za Noć muzeja ${ }^{7}$, Dan muzeja te lokalni festival Aurea fest. Naime za tih dana, u organizaciji muzeja, brijačnica se doista na opću radost građana pretvarala u živi muzej u kojemu nisu glumljene uloge brijača i mušterija nego su $\mathrm{s}$ unajmljenim profesionalnim brijačima postale stvarne. Uz to su promišljeno dodavani detalji koji su upotpunili požeški povijesni

\footnotetext{
Milanović, Tomislav. 2015. Zadnji radni dan požeškog brice. 034Portal online. 18. 11. 2015. https:// www.034portal.hr/index.php?id=19908 i Blašković Vjeran. 2015. Svima je stalo da antikvitetni interijer bricinog salona postane turistička atrakcija. 034 Portal online. 26. 11. 2015. https://www.034portal.hr/ index.php?id=20008

4 Navedena brijačka cjelina upisana je na Listu zaštićenih kulturnih dobara pod brojem Z-6094.

5 Inventar brijačnice čuva se u Povijesnoj zbirci Povijesnog odjela Gradskog muzeja Požega s inv. brojem 28.142

6 Prostor u kojemu se nalazi inventar brijačnice u vrijeme otkupa bio je u vlasništvu Grada Požege, no procesom denacionalizacije vraćen je u privatni posjed.

7 AGM Kruna.2016. Otvoreni muzej ‘Ajmo (se) brijat’. Glas Slavonije online. 19. 11. 2016. http://www.glasslavonije.hr/317711/4/Otvoreni-muzej---Ajmo-se-brijat i Čuljak, Slavenko. 2016. Požeška Noć muzeja: U dobru i u zlu. Radio Vallis aurea online. 24. 1. 2017. https://www.rva.hr/vijest/2017/4896-pozeska-nocmuzeja-u-dobru-i-zlu.
} 
ambijent poput specifičnih tradicijskih muških kolača muškacona iz Muzeja u loncu u obliku leptir-mašne, predstavljanja žestokih pića lokalnih proizvođača, puštanja vintage glazbe, organiziranja natjecanja najljepše uređene brade uz dodjelu muzejskih nagrada - 'bradatih' replika kamenih konzola s Rudine'.

Sve je to, kao i osnaženi trend otvaranja vintage barber shopova u cijeloj Europi, pa tako i u Hrvatskoj (Dimšić, 2016: 101), ohrabrilo muzej u nakanama jedinstvene interpretacije obnove tradicijskog uređenja frizura i brada, ali prije svega njegovanja i prenošenja nematerijalne kulturne baštine u samoj brijačnici kao prostoru muškog druženja9.

No i u ovom projektu požeški je muzej zagrizao tvrd orah. Nabava i pravdanje materijala za brijanje i šišanje, financijsko pravdanje računa za vršenje usluga šišanja i brijanja te opravdanost korištenja brijačkog namještaja koji je muzejski predmet unatoč pozitivnim sugestijama konzervatorske struke ${ }^{10} \mathrm{i}$ denacionalizacija prostora problemi su koji su u jednom času postali nepremostiv problem za požeške muzealce.

Uza sve probleme i činjenicu da se Gradski muzej Požega kao ustanova u svojoj strategiji iz 2018. godine odredila kao ustanova u kojoj takvi projekti nisu prepoznati $^{11}$, projekti otvorenog muzeja poput Muzeja u loncu i Muzejske brijačnice 'Ajmo (se) brijat!' obeshrabreni su u daljnjem razvoju i dostizanju konačnih ciljeva unutar same ustanove.

\section{Običaj Grgureva}

Gore spomenutim baštinskim dobrima treba pridodati i jedinstveni požeški vinogradarski običaj Grgureva, zaštićenog nematerijalnog kulturnog dobra Republike Hrvatske $^{12}$. Riječ je o običaju koji je vezan za povijesni događaj, odnosno legendu prema kojoj se posljednja bitka za oslobođenje Požege od Turaka uz vodstvo fratra Luke Ibrišimovića Sokola i veliku podršku građana odigrala na Svetog Grgura 1688. godine. U sjećanje na taj događaj požeški vinogradari u svojim vinogradima

\footnotetext{
Topić, Jelenko. Najljepše brade imaju Požežani Danijel Banovac i Marijan Paulić te Zvonimir Gelenđer iz Zagreba. Požega.Eu Portal online. 2. 9. 2017. https://pozega.eu/najljepse-brade-imaju-pozezanidanijel-banovac-mario-paulic-te-zvonimir-gelender-iz-zagreba/ i Muzejska brijačnica dodijelila nagrade Najbradama. 2017. Požeška kronika online. 2. 9. 2017. https://pozeska-kronika.hr/zanimljivosti/ item/9718-muzejska-brijacnica-dodijelila-nagrade-najbradama.html.

9 Ozbiljan interes da svoj obrt u budućnosti prenese u požešku Muzejsku brijačnicu i radi po koncepciji projekta kao brijač i interpretator baštine pokazao je vlasnik jednog kultnog zagrebačkog vintage barber shopa.

10 Dokumentacija o tome čuva se u Gradskom muzeju Požega.

11 Strategija Gradskog muzeja Požega, 2018., Analiza, SWOT analiza, str. 3.

12 Ministarstvo kulture Republike Hrvatske zaštitilo je običaj Grgureva kao nematerijalno kulturno dobro Republike Hrvatske pod oznakom (Z-3614) 2007. godine.
} 
na obroncima Požeške gore iznad samoga grada svake godine evociraju uspomenu na bitku i vlastito sudjelovanje u oslobođenju pucanjem iz malih topova te pjesmom i uživanjem u domaćem jelu i vinu u krugu najužeg društva prijatelja uz napomenu da je svaki gost dobrodošao (Žebčević Matić, 1996: 203).

U određenim povijesnim okolnostima Grgurevo je doživljavalo brojne transformacije o kojima je ovisila i autentičnost običaja (Žebčević Matić, 2019: 19). Na to nas je dodatno upozorio Program Požega, Grgurevo i tradicijsko vinogradarstvo požeškoga kraja, u okviru koje je provedena anketa učenika Gimnazije (Jurković, 2019: 30). Naime, tijekom posljednjih tristotinjak godina običaju Grgureva oduzimani su, odnosno dodavani elementi ovisno o trenutnoj društveno-političkoj situaciji u zajednici koja je običaj ignorirala ili glorificirala. Tako je bilo perioda poput komunističkog režima u drugoj polovici 20. stoljeća, kada je običaj bez najjačeg elementa pucanja, gotovo jedva preživio zahvaljujući zatvorenim obiteljskim vinogradarskim proslavama, ali i perioda kada se poslije osamostaljenja hrvatske države prometnuo u vrlo važan događaj koji se obilježavao danima. Stoga, unatoč činjenici da se od 2000. godine Grgurevo slavi i kao Dan grada te mu se pridaje važnost u organizaciji uz angažman ne samo vinogradara nego i cijele društveno-političke zajednice, začuđuju rezultati spomenute ankete koji svjedoče o tome da poražavajuće malo građana, posebice mladih, zna nešto više o samom običaju, odnosno da većina 'tjeranje Turaka' ne doživljava kao dio svojeg identiteta. Posljednjih godina, u želji da se iskoriste turistički kapaciteti običaja, Grgurevo se u gradu i u vinogradima, u turistima prilagođenoj formi, slavi vikend prije, odnosno poslije 12. ožujka, tradicijskog Grgureva. Uz promjenu datuma, promjenu elemenata, nedostatak entuzijazma uživljavanja građana i zakonsko ograničavanje pucanja na otvorenom, Grgurevo iako je zaštićeno nematerijalno dobro Republike Hrvatske - na sam dan 12. ožujka obilježava sve manje aktivnih vinogradara.

Činjenica da dio građana, posebno mladih, ne zna puno ili gotovo ništa o običaju Grgureva kao ni o pripremi tradicijskih jela, odnosno vještini brijanja i druženja u brijačnicama, dovodi do nestajanja dijela baštine, ali i identiteta zajednice. Radi zaštite tih baštinskih dobara, osvještavanja, samoodrživog očuvanja, aktivnog sudjelovanja i samim tim točne interpretacije materijalne i nematerijalne kulturne baštine Požege, potaknuti smo na razmišljanje i traženje stručnih rješenja, oblika i modela djelovanja koji će prebroditi nastale probleme.

Jedno od kvalitetnih i sustavnih rješenja koje nam nameće suvremena svjetska i hrvatska muzeologija jest okupljanje zajednice (u formalnom i najširem smislu) i stručnjaka (muzealci, konzervatori, muzeolozi) oko osnivanja ekomuzeja radnog naziva Požega. 


\section{Što su ekomuzeji}

U svojim istraživanjima i analizama ugledni hrvatski muzeolog dr. sc. Tomislav Šola ustvrdio je da je muzejska djelatnost u povijesnim okolnostima kao i samom svojom prirodom i inercijom u zaostatku za većinom drugih profesija. Međutim, budućnost muzeja koju trenutno doživljavamo pojačanim angažmanima muzeja oko projekata koji mijenjaju odnos s posjetiteljima, a nisu nužno vezani uz zbirke, počela je upravo patentom ekomuzeja - sve to kako bi muzej služio zajednici i njezinu razvoju u najboljem smislu te riječi, a ne samo njezinu prestižu, ukrasu i ponosu (Šola, 1991: 301).

Ipak, imajući na umu ograničenja tradicionalnih (klasičnih) muzeja, posebno u manjim sredinama, te, s druge strane, potrebu aktivne zaštite i stvaranja uvjeta za samoodrživost žive baštine u kojoj uz stručnjake sudjeluje cijela zajednica, uz svjetsku, posljednjih se desetljeća i domaća javnost okrenula sve aktivnijim promišljanjima i realiziranju muzeološke prakse ekomuzeja. Štoviše, u Hrvatskoj se novim Zakonom o muzejima konačno poradilo na pronalaženju pravnog okvira za tu formu muzeja. $^{13}$

Na početku 70-ih godina 20. stoljeća, zahvaljujući Huguesu de Varineu, Georgesu Henriju Riviereu i Marcelu Evrardu, u Francuskoj je na teritoriju propalih industrijskih kompleksa na gotovo $500 \mathrm{~km}^{2}$ između gradova Le Creusot i Montceau les Mines, o kojima je ovisilo 150.000 lokalnih stanovnika, započeo razvoj koncepta prvog suvremenog ekomuzeja pod nazivom Muzej čovjeka i industrije (Babić, 2009: 222).

Cilj tog ekomuzeja bio je ne samo da pokrene propalo gospodarstvo nego da pomogne lokalnom stanovništvu u ponovnom pronalaženju smisla, vlastitog identiteta i otvaranja razvojnih mogućnosti, a sve to na temeljima baštine. Uz središte i kao početna točka za upoznavanje i istraživanje, dakle svojevrsni interpretacijski centar povijesnog razvoja i glavnih obilježja regije, određen je dvorac obitelji koja je nekada bila u vlasništvu posjeda. Međutim značajan odmak od dotadašnje muzejske prakse jest to što su na cijelom području paralelno razvijani fragmentarni oblici muzeja in situ. Ono što je pritom bilo vrlo važno i što je imalo presudno značenje u cijelom projektu jest sudjelovanje lokalnog stanovništva, koje je time postalo i publika i korisnik, odnosno Muzej čovjeka i industrije postao je važno sredstvo za obrazovanje širokih slojeva društva, mehanizam utjecanja na formiranje svijesti i vlastitog vrednovanja (Babić, 2009: 223).

Tada je ekomuzeološki koncept zaživio u praksi u nizu europskih zemalja počevši od Francuske, Španjolske, Portugala te nešto kasnije Italije (90-ih godina 20. stoljeća) i skandinavskih zemalja preko Latinske Amerike, Kanade, Sjedinjenih Američkih Država do Japana, Vijetnama i Kine (potkraj 20. i početkom 21. stoljeća).

13 Zakon o muzejima NN 61/18, 98/19. 
Drugim riječima, o ekomuzejima možemo govoriti kao o globalnom fenomenu koji, prema dostupnim podatcima, obuhvaća oko 400 ekomuzeja rasprostranjenih diljem svijeta (Batina, 2013: 24).

Vrlo je važno napomenuti da ne postoje dva jednaka ekomuzeja, odnosno da svaki postojeći ima svoje specifičnosti koje definira lokalna situacija prilagođavajući ih promjenama, jer je osnovna pretpostavka da "ekomuzej naprosto treba živjeti“ (Babić, 2009: 227).

Pri tome je vrlo važno napomenuti, kako bi se uklonila moguća zabuna, da ekomuzeji u svojem djelovanju obuhvaćaju i ekološku sastavnicu, ali pojam okoline ne percipiraju samo kroz prirodno nego i kroz društveno i tehničko okruženje (Batina, 2013: 18).

Iako je do sada muzeologija iznjedrila mnoge definicije ekomuzeja, navest ćemo - kako bismo približili bit tog koncepta - definicije Georgesa Henrija Riviere, jednog od glavnih aktera u stvaranju ekomuzeja. Dakle, on kaže da se radi o muzeju novog žanra koji počiva na interdisciplinarnosti, organskoj povezanosti sa zajednicom u kojoj djeluje; odnosno po njemu je ekomuzej instrument koji zajednički osnivaju, proizvode i koriste lokalna uprava (sa svojim stručnjacima, olakšicama, izvorima financiranja) te populacija (prema svojim aspiracijama, znanjima i sposobnostima približavanja) (Babić, 2009: 228).

Sistematizirane definicije ukazuju na širok raspon shvaćanja fenomena te muzejske forme: od muzejske institucije preko baštinskih projekata do instrumenata (oruđa, alata, mehanizma) razvoja koji na dinamičan način (baštinske akcije), na određenom teritoriju i uz temeljnu potporu zajednice (lokalnog stanovništva, lokalnih stručnjaka i profesionalaca), imaju za cilj prepoznati, istražiti, zaštititi, interpretirati i prezentirati naslijeđene baštinske vrijednosti koje sadržavaju važna obilježja identiteta pojedinaca ili kolektiva te ih kontinuirano komuniciraju budućim naraštajima u svrhu očuvanja identiteta, planiranja i održivog razvoja zajednice. Ključni pojmovi pokušaj su da se sveobuhvatan pojam ekomuzeja sažme na njegove osnovne odrednice: identitet, kontinuitet, teritorijalnost, održivost i razvoj, društveni aktivizam ${ }^{14}$.

Kada je inicijativa za uspostavu Europske mreže ekomuzeja 2004. godine u Trentu na poticaj predstavnika dvadesetak ekomuzeja iz Italije, Poljske, Češke i Švedske definirala ekomuzej kao dinamički način na koji određena zajednica čuva i interpretira vlastitu baštinu te upravlja njome u pravcu održivog razvoja (Babić, 2009: 229), Hrvatska je već imala svoj prvi Ekomuzej batana. ${ }^{15}$

14 Isto, str. 21-22.

15 Od elaborata Ekomuzeja Blaca idejnog začetnika dr. sc. Tomislava Šole iz 1982. godine kojim se nastojao zaštititi i revalorizirati čitav samostanski kompleks svećenika glagoljaša iz 16. stoljeća na otoku Braču, jedinstveni harmonični spoj znanstveno-kulturnog nasljeđa i otočnog krajolika koji afirmira vrijednost samostanskog života i rada pa do realizacije prvog ekomuzeja, Ekomuzeja batana, 2004. godine trebala su proći puna dva desetljeća. 
Ekomuzej batana autorice Lucije Dragane Ratković Aydemir posvećen je tradicijskom drvenom plovilu batani, koja predstavlja simbol kontinuiteta pomorske i ribarske baštine rovinjske zajednice. Poslanje i ciljevi Ekomuzeja batana odnose se upravo na očuvanje i komuniciranje materijalne i nematerijalne maritimne baštine te osnaživanje kulturnog identiteta i posebnosti grada Rovinja ${ }^{16}$.

Iako je počeo kao interpretacijski centar pod upravom Zavičajnog muzeja grada Rovinja, Ekomuzej batana morao je izaći iz tradicionalnog koncepta upravljanja muzeja zbog nemogućnosti integriranja živih procesa koje su u samoj srži tog ekomuzeja te se osamostaliti kao nevladina udruga (Ratković Aydemir, 2013: 40). Zahvaljujući brojnim nagradama i priznanjima za različite aspekte djelovanja, Ekomuzej batana postaje lučonoša ekomuzeologije u Hrvatskoj kao primjer isticanja važnosti valorizacije kulturnih identiteta lokalnih zajednica kao fleksibilan model njezina očuvanja (Ratković Aydemir, 2013: 41).

Ohrabrena entuzijastičnom podrškom lokalne zajednice koja je u projektu Ekomuzej batana generirala preko 100 volontera, $\mathrm{u}$ okviru svoje tvrtke za savjetovanje i upravljanje projektima u kulturi i turizmu Muze d.o.o. iz Zagreba, Dragana Lucija Ratković Aydemir tijekom proteklih godina sudjelovala je u izradi niza idejnih projekata za osnivanje ekomuzeja. Najčešće su to projekti u okviru lokalnih i regionalnih razvojnih strategija u želji povlačenja novca iz europskih fondova te upravljanja njihovom implementacijom ${ }^{17}$, poput Ekomuzeja Rakovica, Ekomuzeja Kuća tartufa u Buzetu, Ekomuzeja Kuće maslina i maslinarstva u Tar Varbarigi, Ekomuzeja čipke i čipkarstva u Lepoglavi, Ekomuzeja Komiža te Ekomuzeja Mošćenička Draga. Navedenima još možemo dodati Ekomuzej Žumberak, Ekomuzej Vlaški puti Šušnjevica, Ekomuzej hrvatskog vinogradarstva i vinarstva u Vinodolu, Ekomuzej Tragovi prošlosti u Sesvetama, Ekomuzej Mura, Ekomuzej Bistra, Ekomuzej Ravni kotari.

Stoga je i više nego dobrodošao znanstveno-stručni multidisciplinarni skup Uloga ekomuzeja u razvoju lokalnih zajednica, koji je održan 12. listopada 2018. u organizaciji Hrvatske sekcije Europskog vijeća za sela i male gradove (ECOVAST HR) i Udruge Ekomuzej Bistra. Neki od zaključaka koje izdvajamo važni su i za razmišljanje o mogućem Ekomuzeju Požega:

- Poželjno je da poticaj za osnivanje ekomuzeja dođe iz lokalne zajednice i njezine svijesti o očuvanju vlastitog identiteta. Cilj osnivanja ekomuzeja nije stvaranje zbirke materijalnih ostataka ni projekcija političke volje. U konceptu

16 Klementina Batina, Eko muzeji i razvoj, Prijedlog baštinskog projekta Ekomuzej Bistra, diplomski rad, Odsjek za informacijske i komunikacijske znanosti, Katedra za muzeologiju i upravljanje baštinom na Filozofskom fakultetu u Zagrebu, 2013., str. 32.

17 Ekomuzeji djeluju najčešće kao udruge građana i koriste se instrumentima suradnje, partnerstva, umrežavanja i baštinskog aktivizma imajući u vidu promicanje kulturološkog dijaloga između država članica sa zajedničkim politikama Europske unije. Projekti s temom obnove i očuvanja baštine financiraju se iz programa teritorijalne suradnje Europske unije koji podupiru regionalni razvoj. 
ekomuzeja najvažniji je stav prema konceptu baštine i ulozi te baštine u životu zajednice.

- Tijekom uspostave i djelovanja ekomuzeja kao baštinskih institucija važno je uključiti stručnjake odgovarajućih stručnih profila. Činjenica da ekomuzeji proizlaze iz lokalnih inicijativa ne smije biti opravdanje za improvizacije i nestručne pristupe.

- Ekomuzeji kao modeli održivog upravljanja prirodnom i kulturnom baštinom uspostavljaju i nove oblike upravljanja, suradnje i koordinacije.

- Važan segment rada ekomuzeja jest i kontinuirana edukacija o vrijednostima sveukupne baštine te komuniciranje baštinskih vrijednosti lokalnom stanovništvu i posjetiteljima u svrhu trajnog očuvanja identiteta (Dejanović; Batina, 2018: 71).

\section{Požeški ekomuzej, da ili ne?}

Zašto da?

1. Sva tri požeška baštinska dobra o kojima govorimo (tradicijska prehrana Požege i Požeštine, umijeće brijanja, jedinstvena sačuvana brijačka cjelina s početka 20. stoljeća, jedinstveni vinogradarski običaj Grgurevo) zaslužuju biti zaštićena, interpretirana i oživljena kao nedjeljiv dio identiteta građana grada Požege.

2. Požega kao urbana cjelina u današnjim okolnostima (globalizma, promjene stanovnika, iseljavanja) sve više gubi svoj identitet, stoga vjerujemo da bi osnivanje Ekomuzeja Požega zaustavilo taj trend.

3. Muzej se zbog objektivnih problema (manjak djelatnika, velika količina građe o kojoj brine, vrlo širok raspon tema, strategija ustanove), osim savjetodavno, ne može posvetiti nijednoj od navedenih tema s potrebnom pažnjom.

4. Muzej u loncu i Muzejska brijačnica dva su projekta s već definiranim ciljevima, vlastitom strategijom, procjenom uspješnosti, rangom važnosti, metodama i rezultatima te svakako zaslužuju daljnji razvoj. Ako tome dodamo trostoljetni zaštićeni običaj Grgureva, koji se trenutno nalazi pred velikim i opasnim izazovima današnjice, osmišljanje strategije za njegovu revitalizaciju zajedno s prva dva pridonijet će razvijanju identiteta stanovnika, ali i samoga grada, profiliranju brendova grada te samoj vidljivosti i turističkoj posebnosti, odnosno privlačnosti.

5. Ekomuzej Požega svakako će osnažiti zajedništvo građana različitih generacija, posebno mlađih, kroz projicirane zajedničke tradicijske vrijednosti ponosa, slobodarstva, druženja, konstruktivne zabave, osobnog doživljaja te brige za 
očuvanje, a da o poticanju građana na to da sami uz stručnjake sudjeluju u smišljanju i realizaciji, ali prije svega konzumaciji, baštine i ne govorimo.

6. Sva tri baštinska dobra mogu se međusobno uspješno povezati kroz cjelogodišnji program koji će osiguravati sredstva za djelomično samoodržavanje (pripremanje i prodaja tradicijske hrane, edukacije, usluge brijanja i šišanja, radionice, novčani prihodi od prodanih monografija običaja Grgurevo, virtualnih igrica...).

Zašto možda ipak ne?

1. Ipak, kao što smo već naglasili, ne postoje dva jednaka ekomuzeja, odnosno uspješno iskustvo jednoga ne znači i uspješnost drugoga. Dakle, nema zagarantiranog uspjeha, najbolji su ekomuzeji oni koji su sami osmislili rješenja i projekte i koji su u potpunosti domaći izumi (Da Graca Filipe; De Varine, 2013: 11).

2. Prije upuštanja u rizik organizacije Ekomuzeja Požega moramo biti svjesni opasnosti koje nosi takav vid organiziranja, od političkog rizika, ekonomskog rizika, smjene generacija i opasnosti od irelevantnosti preko snage pojedinačnih interesa, opasnosti od skupljanja i upravljanja mogućim vlastitim zbirkama, opasnosti od statične zaštite baštine pa sve do opasnosti od pretjerane standardizacije i profesionalizacije (Da Graca Filipe; De Varine, 2013: 6-12).

Ekomuzej Požega sa svim svojim komponentama može postati nanovo stvorena muzejska stvarnost koja se može mijenjati i transformirati do one granice do koje neće iznevjeriti temeljnu muzejsku i baštinsku poruku. Konačno, u tome je perspektiva novih muzejskih tendencija (Maroević, 1985: 18).

Vrijedi razmisliti.

\section{Literatura}

Babić, Darko (2009), Iskustva i (skrivene) vrijednosti eko-muzeja. Etnološka istraživanja 14, str. 221-236.

Da Graca Filipe, Maria, De Varine, Hugues (2013), Kakva je budućnost eko muzeja? Informatica muzeologica 44 (1-4), str. 6-24.

Dejanović, Antonija, Batina, Klementina. (2018), Uloga ekomuzeja u razvoju lokalnih zajednica. Vijesti muzealaca i konzervatora 2018, str. 68-71.

Dimšić, Katarina (2016), Semiotički prikaz brkova i brada uz izložbu Puna šaka brade. Etnološka istraživanja 21, str. 101-110.

Maroević, Ivo (1985), Od muzeja na otvorenom do ekomuzeja. Informatica Muzeologica 15, str. 18-19.

Ratković Aydemir, Lucija Dragana. (2013), Ekomuzej batana, Rovinj - Rovigno Hrvatska ekomuzeologija „na mala vrata“. Informatica muzeologica 44 (1-4), str. 35-47. 
Šola, Tomislav (1985) Od muzeja na otvorenom do eko-muzeja. Informatica muzeologica 15, str. 18-19.

Šola, Tomislav (1991), Nove tendencije u teoriji i praksi muzeja xx stoljeća. Osječki zbornik 21, str. 301-308.

Uzelac, Zlatko (1985), Međunarodni dan muzeja na požeškom trgu - drugi put. Informatica muzeologica 15, str. 35-37.

Žebčević Matić, Maja (2019), Zajedništvo slavonskih muzeja kroz projekt Muzej u loncu. Glasnik slavonskih muzeja (XXX) 7, str. 229-230.

\section{Izvori}

Batina, Klementina (2013), Eko muzeji i razvoj, Prijedlog baštinskog projekta Ekomuzej Bistra, diplomski rad Odsjek za informacijske i komunikacijske znanosti, Katedra za muzeologiju i upravljanje baštinom na Filozoskom fakultetu u Zagrebu,

Pačić, Vlasta (1990), Otvoreni muzej - muzej budućnosti, diplomski rad, Sveučilište "Vladimir Bakarić" u Rijeci Pedagoškog fakulteta Rijeka

Sokaš Štimac, Dubravka, Šperanda, Mirkana, Španiček, Lidija, Matoković, Dubravka, Žebčević Matić, Maja. Muzeološka koncepcija Gradskog muzeja Požega, 2005.

Zakon o muzejima NN 61/18, 98/19.

Milanović, Tomislav. 2015. Zadnji radni dan požeškog brice. 034Portal online. 18. 11. 2015. https://www.034portal.hr/index.php?id=19908

Blašković Vjeran. 2015. Svima je stalo da antikvitetni interijer bricinog salona postane turistička atrakcija. 034 Portal online. 26. 11. 2015. https://www.034portal.hr/ index.php?id=20008

AGM Kruna. 2016. Otvoreni muzej 'Ajmo (se) brijat'. Glas Slavonije online 19. 11. 2016. http://www.glas-slavonije.hr/317711/4/Otvoreni-muzej---Ajmo-se-brijat i

Čuljak, Slavenko. 2016. Požeška Noć muzeja: U dobru i u zlu. Radio Vallis aurea online. 24. 1. 2017. https://www.rva.hr/vijest/2017/4896-pozeska-noc-muzeja-u-dobru-i-zlu

Topić, Jelenko. Najljepše brade imaju Požežani Danijel Banovac i Marijan Paulić, te Zvonimir Gelenđer iz Zagreba. Požega. Eu Portal online. 2. 9. 2017. https://pozega. eu/najljepse-brade-imaju-pozezani-danijel-banovac-mario-paulic-te-zvonimirgelender-iz-zagreba/

Muzejska brijačnica dodijelila nagrade Najbradama. 2017. Požeška kronika online. 2. 9. 2017. https://pozeska-kronika.hr/zanimljivosti/item/9718-muzejska-brijacnicadodijelila-nagrade-najbradama.html 


\section{Prilozi}

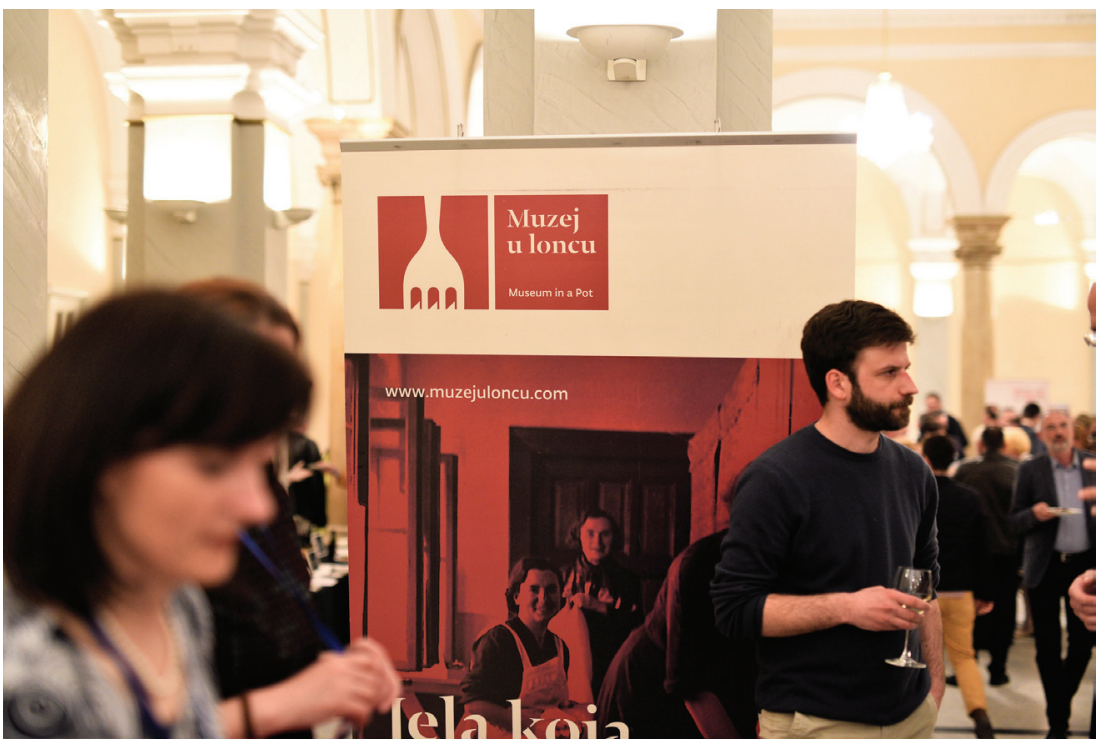

Slika 1. Predstavljanje monografije Muzej u loncu u Muzeju Mimara, 10. travnja 2018.

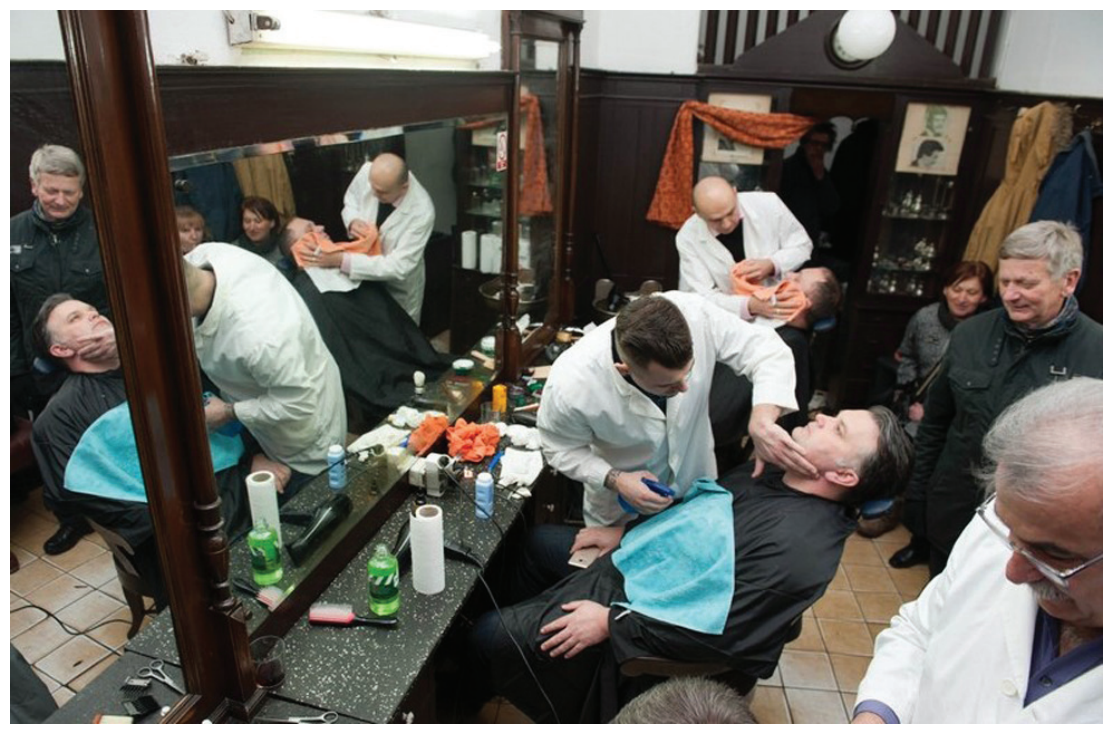

Slika 2. Muzejska brijačnica, Noć muzeja, 27. siječnja 2017. 


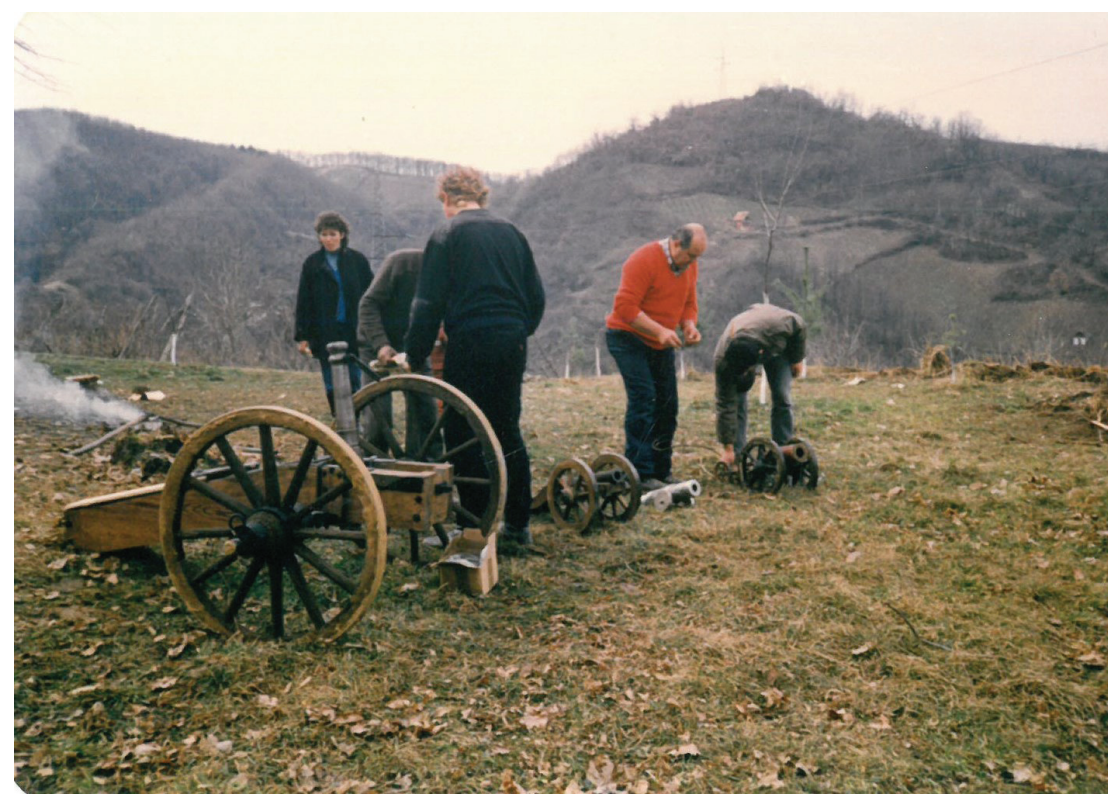

Slika 3. Grgurevo, Društvo barutara, vlasništvo Marijana Grpca 


\section{Museum in the Pot, Barbershop Museum, Grgurevo: Požega Eco-Museum - Pros and Cons}

\section{Summary}

Being a town rich in cultural heritage and creative people, Požega deserves at least considering the idea of opening an eco-museum as a way of modern museological interpretation, resting upon togetherness with the entire community.

The fact however remains that unusual projects, which exceed the boundaries of ordinary museum operation and way of thinking, cannot take root in communities such as ours.

Judging by the cases of the Museum in the Pot (an unusual interpretation of nonmaterial cultural heritage by the means of the taste and smell of the forgotten dishes) and the Barbershop Museum (the idea of which rests upon reliving an existing museum exhibit in situ - furniture and equipment of an early-20 ${ }^{\text {th }}$-century barbershop), the principal difficulty lies in having to deal with additional organizational and legal limitations and demands parallel with the regular ongoing museum activities and existing problems.

Hence, the problems arising from these two projects might potentially be solved by forming a unique eco-museum, which could gather the community around a selfsustaining model for presenting the spirit and the traditional way of life in the past.

Additionally, due to the new conditions, even the Grgurevo custom has become drastically changed and poorly managed. It has thus lost its identity and strength in the community, which has ceased to regard it as a part of its identity. Consequently, Požega Eco-Museum should be seriously considered.

Keywords: Eco-Museum; Museum in the Pot; Grgurevo; Barbershop Museum.

Maja Žebčević Matić, dipl. etn., muzejska savjetnica

Gradski muzej Požega

Matice hrvatske 1, 34000 Požega

maja@gmp.hr 